\title{
The Role of New Development in Enhancing the Livability of Historic Urban Quarters, Case Study the Walled City of Famagusta, North Cyprus
}

\author{
Seyed Nima Mousavi ${ }^{1}$ and Seyed Sina Mousavi ${ }^{2}$
}

\begin{abstract}
Most cities have a historical and cultural quarter which introduce and shows the identity and sense of the place of area. These quarters are a fundamental part of the city and their visual and functional qualities are important principle and elements of the city's image. In addition, due to the location of these quarters, which often located in central part of the city their revitalization is often part of the general revitalization plan of cities. Attracting diversity of users and more importantly people to live in these areas is one of the main challenges with cities and urbanity. All urban areas during the time facing different changes, but historic urban quarters have to corporate with change in a correct way for reaching and enhancing the livability. These places have additional concern and view on the quality of design of new developments and on the quality of spaced between the buildings. In these quarters, the necessity of merging and balancing the various needs of conservation and revitalization process and new development while concerning historical and cultural heritage and quality of environment is one of the big challenges. In addition it is visible that the role of new development has direct relation with revitalization in historic urban quarters. The main aim of this research is to define and examine the relation between new buildings and revitalization in historic urban quarters.
\end{abstract}

Keywords-New Development, Livability, Revitalization, Historic urban quarters, sense of place.

\section{INTRODUCTION}

It is widely accepted that historic urban quarters have a special place in the cultural and historical heritage of any country. As they are coherent entities, they are noticeably identified by their traditional character and architectural value. They reflect the endeavors of different important cross-section of the world cultures, and while some represent and characterized the efforts of original cultures. All mingle their diverse influences in creative fashion to create unique forms and patterns of use. Because of the heritage value of these areas, these quarters are worthy of revitalization and conservation. "The qualities of these special areas were often not appreciated until the 1960s, and individual buildings, structures and other artifacts were subject to "preservation"”." Nowadays, the foundation sustaining the phenomenon of

${ }^{1} \mathrm{PhD}$ Candidate and Research Assistant, Eastern Mediterranean University, Faculty of Architecture, North Cyprus.

${ }^{2} \mathrm{PhD}$ Candidate, Eastern Mediterranean University, Faculty of Architecture, North Cyprus. revitalizing historic urban quarter is widely known in global scale (Doratli et al. 2004).

Today livability is one of the main issues throughout the world. In general livability has rolled in three main areas: environmental quality, neighborhood amenity and individual well-being. Generally, the concept of livability involves different aspects of urban life; how well the city works for us, as well as how comfortable and enjoyable our neighborhood and city are (Mousavi, 2012).As stated by Tiesdell et al., historic urban quarters are part of an economic dynamic; they are rarely autonomous functioning zones and usually have a symbiotic relationship with the rest of the city. They must therefore be considered within the context of the city as a whole and their conservation has to be considered, not as a straightforward and restrictive concern for preservation, but as a concern for revitalization and enhancement (Doratli et al. 2004).

The main aim of this article is to achieve the relationship between the new development and enhancing the livability in historic urban quarters. The methodology method is literature survey, and using the information of the master thesis which related to Livability in historic urban quarters done by the author. The first part of the research is related to theoretical framework which concentrates on livability dimension and design principles for new development in historic urban quarters and the second part is related to finding the relation between livability and new development. And the last part is related to proposing some recommendation and suggestion for reaching the livability in area by new development. The case study of this research is the Walled city of Famagusta.

\section{LIVABILITY DIMENSION}

According to Oxford dictionary (2010) livable means 'fit to live in'. EIU (2011) describes livability as one of the characteristics that could collaborate to high quality of living. Because high quality of life impresses the lifestyle, health condition and represents permanence and strength of the built environment. Generally main city centers around the world would struggle to keep themselves safe, to improve health condition of the citizens, maintaining "economic stability" and preparing suitable and functional transportation network and system (Mousavi, 2012).

In general term, the dimensions of livability will be different according to the culture and location or situation. 
According to Yeang livability has four dimensions: The environmental quality, place quality, which is related to physical features, place quality, which is related to functional features and safer places, which are related to social issues (See Table 1). These four dimensions are the main dimensions of livability. However "it should be noted that these dimensions might not have exact the same content and meaning in all researchers or studies, even though the same term might be used" (Mousavi, 2012).

\begin{tabular}{|c|c|}
\hline Liveability dimension & Theme \\
\hline $\begin{array}{l}\text { Social dimension } \\
\text { (social relations) }\end{array}$ & $\begin{array}{l}\text { behaviour of neighbours (nuisance) } \\
\text { community life and social contact } \\
\text { sense of place }\end{array}$ \\
\hline $\begin{array}{l}\text { Physical dimension } \\
\text { (residential environment) }\end{array}$ & $\begin{array}{l}\text { environment quality } \\
\text { open spaces } \\
\text { maintenance of built environment }\end{array}$ \\
\hline $\begin{array}{l}\text { Functional dimension } \\
\text { (facilities and services) }\end{array}$ & $\begin{array}{l}\text { availability and proximity of amenities } \\
\text { accessibility } \\
\text { employment opportunities }\end{array}$ \\
\hline $\begin{array}{l}\text { Safety dimension } \\
\text { (crime and sense of } \\
\text { safety) }\end{array}$ & $\begin{array}{l}\text { number of crime } \\
\text { number of accidents } \\
\text { feeling of safety }\end{array}$ \\
\hline
\end{tabular}

In social dimensions various elements about community life and social contact are mentioned. Also "neighbor's behavior in terms of nuisance" and sense of place along with the relationship between neighbors are the other concerns in this category. Other elements and themes might be taken into consideration such as "access to affordable housing which is a key component of a livable city as it determines whether people can actually live in it." And "creating separate neighborhoods for people of different income levels to encourage a fragmented rather than a tolerant and diverse culture". In addition "by building high density and different housing types within neighborhoods, communities can provide housing options at different pricing levels". A livable city is a city which discovers strength point in "the interactions of people from different perspectives and backgrounds. By placing diverse groups of people within one community, social diversity is supported and tolerance is nurtured. In order for a city to welcome people of different income levels, they need to be provided with affordable places to live" (Mousavi, 2012). The next dimension is related to the safety and crime, generally, safety is one the most important needs in every society and citizens desire to live in a safe neighborhood. In a neighborhood with high crime rate, it is impossible to maintain high quality of life due to significant influence and impact of unsafe places in citizen's life even though other conditions are met. According to Savasdisara's (1998) studies in Japanese communities' safety and security is one of the main elements of quality of life and living conditions. The indicator which measure safety dimension is "neighborhood's safety level". It is divided into three types, "the frequency of different types of crime (homicide, property crime and sexual assaults), incidents of injuries or accidents and feelings of security" (Mousavi, 2012).
The next dimension is related to physical dimension, the physical environment is the place, where people work, live and communicates with each other (Lau Leby.J \& Hariza Hashim.A 2010). According to Yeang the elements and indicators, which are in this category, is related to the quality of built environment, quality of parks and land, public realm quality and levels of derelict land (Yeang, L.D, 2006). Also according to Heylen's (2006) "the availability of amenities and services" is related to this category. The last dimension is related to functional dimension, according to Holt-Jensen (2001) the functional indicators is related to well-being which "depends on good provision and location of communication systems, shops, kindergartens, shopping centers, clinics, schools and other services". The other factor which relates to this category is about accessibility (Lau Leby.J \& Hariza Hashim.A 2010).

New development in different places could be variable in each places due to the different culture and heritage elements, each places has its own policy and principle for development in historic urban quarters so it is not possible to reach a general principle and policy for every place but some of the main principle which will be similar in each places will be mentioned in this article. The new development and revitalization in historic urban quarters divided into two processes, the first process is related to rehabilitation which aims to improve economic condition of place by lots of changes and the second process is related to preservation which aims to reduce the changes and protect and preserve historic area and building (Tiesdell, et al. 1996).

The main characteristic of new development is divided into two dimensions, the first dimension is related to spatial characteristic dimension and the second dimension is related to architectural characteristic (Visual characteristic) dimension, each of these dimensions has indicators, these indicators will be mentioned in further part.

"The spatial characteristic approach related to the continuity of building lines and street frontages to enhance and reach street containment and enclosure. It generally permits little scope for the design of buildings as an object in space, the building as a self-referential entity without a positive design of that space. A location where a highly landmark building might be appropriate is at significant point for the legibility of townscape, such as street corner or the termination of a particular view or vista" (Tiesdell, et al. 1996).In general spatial characteristic consist of different parameters, these parameters are: Urban structure, Density and Diversity of users, landscape design, Views and Landmarks.

- Urban structure: New development should respect and contribute the existing and original urban structure of place. The urban pattern of area consists of the pattern of street or building. In some locations, the urban structure may have been compromised by previous development or demolition and new development will present an opportunity to repair the damage. This does not mean unoriginal reconstruction of lost urban structures but it does ensure that a knowledge and understanding of urban structures has been taken into account in the design process (New Design in Historic Settings, 2010). 
TABLE II: PHYSICAL DIMENSION AND INDICATORS (MOUSAVI, 2012)

\begin{tabular}{|c|c|c|c|}
\hline Dimensions & Parameters & Indicators & Crite ria for Indicators \\
\hline \multirow{24}{*}{ Physical } & \multirow{10}{*}{$\begin{array}{l}\text { Quality of Built } \\
\text { Environment }\end{array}$} & \multirow{2}{*}{ Green Space } & Ratio of green space to built surfaces \\
\hline & & & Green surface to built surface density \\
\hline & & \multirow{2}{*}{ Density } & Total builtup area to site area \\
\hline & & & Ratio of population density \\
\hline & & \multirow[b]{2}{*}{ Clean Environment } & General Sanitary condition \\
\hline & & & Municipality garbage collection \\
\hline & & \multirow{2}{*}{ Noise and Safety } & $\begin{array}{l}\text { Proximity to noise gene rating } \\
\text { activities in the vicinity }\end{array}$ \\
\hline & & & Safe walking throughout the day \\
\hline & & \multirow{2}{*}{ Vis ual Character } & $\begin{array}{l}\text { Building materials, Colour and } \\
\text { texture }\end{array}$ \\
\hline & & & Harmony in façade building \\
\hline & \multirow{12}{*}{$\begin{array}{l}\text { Public Realm } \\
\text { Quality }\end{array}$} & \multirow{2}{*}{ Condition and Maintenance } & $\begin{array}{l}\text { The overall structural condition of the } \\
\text { building }\end{array}$ \\
\hline & & & $\begin{array}{l}\text { Degree of maintenance of buildings } \\
\text { to public spaces }\end{array}$ \\
\hline & & \multirow{3}{*}{ Design } & Well-designed \\
\hline & & & Legible \\
\hline & & & Has a sense of enclos ure \\
\hline & & \multirow{4}{*}{ User } & Healthy \\
\hline & & & Has a space for social interaction \\
\hline & & & Fulfilling \\
\hline & & & Relaxing \\
\hline & & \multirow{3}{*}{ Function } & Community resource \\
\hline & & & Vital and viable \\
\hline & & & Functional \\
\hline & \multirow{2}{*}{$\begin{array}{l}\text { Levels of De relict } \\
\text { and Vacant Land }\end{array}$} & Ratio of vacant area to build area & $\begin{array}{l}\text { Total area of vacant area to total } \\
\text { built area }\end{array}$ \\
\hline & & $\begin{array}{c}\text { Ratio of vacant building to total } \\
\text { building }\end{array}$ & $\begin{array}{l}\text { Total area of vacant building to total } \\
\text { built area }\end{array}$ \\
\hline
\end{tabular}

- Density and Diversity of users: Density and mix of uses are important principle and elements in creating the variety and vitality for an area. Density is the amount of development that can be used on a specific piece of land and will be different according to the type of use. New development in historic area can respond to the amount, nature and mix of current uses, especially where they are typical to the area and relate to its historical growth (New Design in Historic Settings, 2010).

- Landscape design: A detailed understanding of the topography of the area is one of the main necessary principal for new design and development. New development should aim to merge and combine with the existing built form without merely copying it. Landscape not only contains the natural features of an area but is also the product of human intervention.
- Views and Landmarks: "Views embrace wide open landscapes whereas existing vistas may be channeled or terminated by landscape features and landmark buildings, intentionally or accidentally. New design should consider ways to enhance or protect their function as landmarks. In some instances new designs might provide the opportunity to create new vistas towards landmarks, restore older views that have been lost or compromised, or create dynamic juxtapositions of old and new, so adding texture and variety to the townscape"(New Design in Historic Settings, 2010). 
TABLE III: FUNCTIONAL DIMENSION AND INDICATORS (MOUSAVI, 2012).

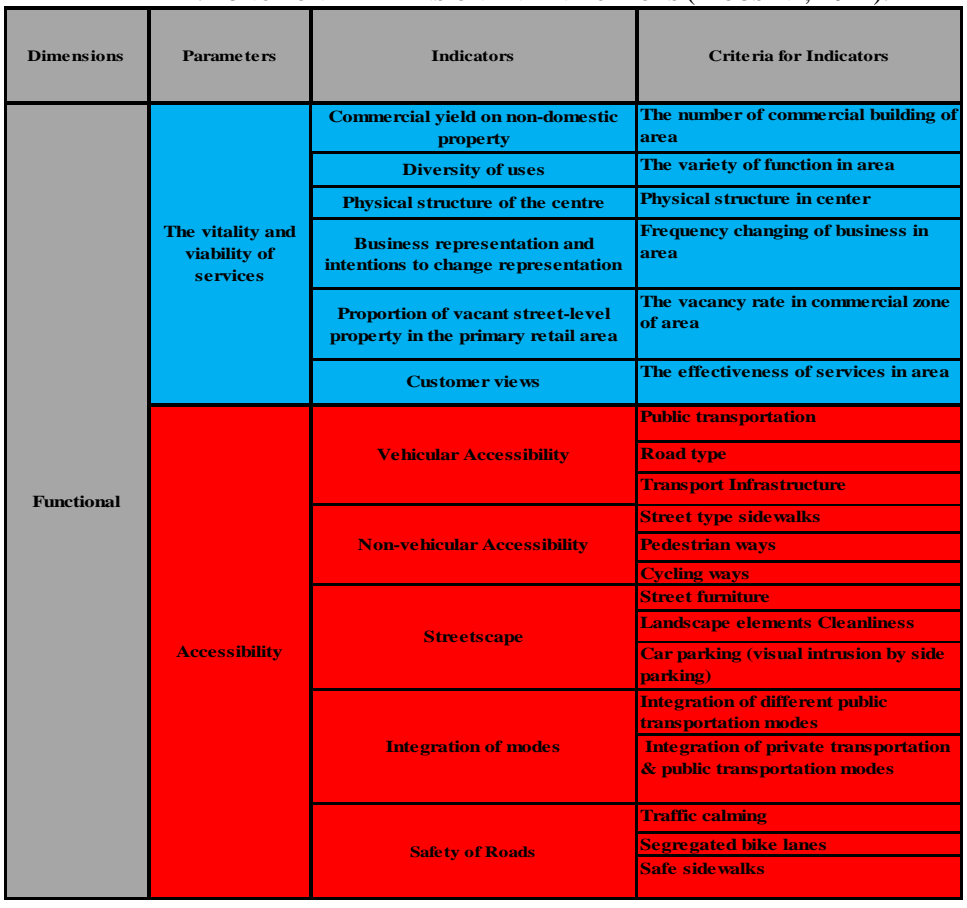

- Urban grain and Permeability: New developments should respect urban grain, the pattern of streets and

TABLE IV: SOCIAL AND SAFETY DIMENSION (MOUSAVI, 2012).

\begin{tabular}{|c|l|}
\hline Dimension & \multicolumn{1}{|c|}{ Parameters } \\
\hline \multirow{2}{*}{$\begin{array}{c}\text { Social } \\
\text { Dimension }\end{array}$} & Behaviour of neighbours \\
\cline { 2 - 2 } & Community life and social contact \\
\cline { 2 - 2 } $\begin{array}{c}\text { Saftey } \\
\text { Dimension }\end{array}$ & Number of Crime \\
\cline { 2 - 2 } & Number of Accident \\
\cline { 2 - 2 } & Feeling safety in area \\
\hline
\end{tabular}

- Architectural characteristic (Visual characteristic): "having created new form and massing that respect the quarter's spatial character; the walls that define those spaces have to be articulated architecturally. Generally the vertical and horizontal rhythms, the arrays and pattern of solid and void, masonry and glazing on building elevation are more important than the precise details of the building's architectural style. To maintain the grain and scale of the quarter, the amalgamation of historic plot divisions should be resisted. Where this is not possible and sites are assembled into larger packages, the scale of the historic plot division should be respected in the elevational designs to ensure consistency with the quarter. Together with the consistent use of materials, such patterns and rhythms, contribute to and establish the architectural character of the quarter" (Tiesdell, et al. 1996). The main parameters of architectural characteristic are: Scale, Materials and detailing, urban grain and permeability, coherency and homogeneity with quarter and contextual harmony.

- Coherency and Homogeneity with quarter: Some quarters possess a virtual architectural homogeneity and coherence, these homogeneity and coherency caused by "concentrated development period and functional requirements" (Tiesdell, et al. 1996). spaces; urban grain tends to be inclined by the rhythm of architectural composition and the fundamental relationship of solid-to-void in buildings. One element of this is the 'permeability' of the grain - that is, how people move between spaces and the nature of long and short views" (New Design in Historic Settings, 2010).

- Scale: New design and development should respect and consider the surrounding scale, proportion and massing of the existing building in area. Scale is made up of height and mass and is mostly relative in that building height is generally apparent in relation to the "height of a person, width of a street or space, nearby buildings, particular landmarks or strategic views." The appropriate scale may also relate to the wider impact of the development.

- Materials and Detailing: The use of appropriate color, texture and pattern of materials, whether traditional or contemporary is important in new development process. Also using the proper material which used in façade is important to reach the harmony in façade.

- Contextual Harmony: One of the main and challenging parameters in new development process in historic urban quarters is "harmony"; the creation of a visually integrated but not necessarily homogenous- townscape. (Brolin, 1980). There are three methods for reaching the contextual harmony. Contextual uniformity, contextual juxtaposition and contextual continuity (Tiesdell, et al. 1996).

- Contextual uniformity: contextual uniformity is the copying or imitation of the neighboring styles.

- Contextual juxtaposition: Rogers argues that a harmonious order can result from the juxtaposition of building of different epochs, each of being the expression 
of its own time. This notion is congruent with ideas of the modernist.

- Contextual Continuity: it stresses the continuity between time frames. Contemporary urban design is concerned with historical continuity of city and of places. This may be characterized as postmodernist view.

As mentioned above, both spatial and architectural characteristic are described in detail these parameters shown in table below (Table 5).

\begin{tabular}{|c|c|}
\hline $\begin{array}{c}\text { New } \\
\text { Development } \\
\text { Charecteristic }\end{array}$ & Parameters \\
\hline \multirow{4}{*}{$\begin{array}{c}\text { Spatial } \\
\text { Characteristic }\end{array}$} & Urban structure \\
\hline & Density and Diversity of users \\
\hline & landscape design \\
\hline & Views and Landmarks \\
\hline \multirow{5}{*}{$\begin{array}{l}\text { Architectural } \\
\text { Characteristic }\end{array}$} & Urban grain and permeability \\
\hline & Scale \\
\hline & Materials and detailing \\
\hline & Coherency and Homogeneity with quarter \\
\hline & Contextual Harmony \\
\hline
\end{tabular}

According to what mentioned before, the main new development value is shown in figure below (Fig.
$1)$.

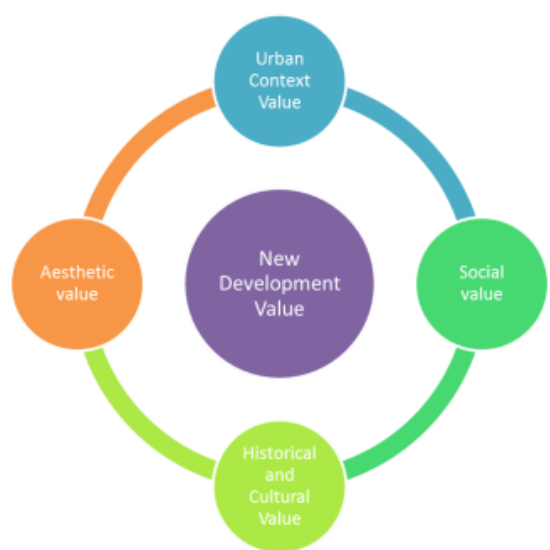

Fig. 1: New Development value

As shown in figure 1, the main new development value is urban context value, social value, aesthetic value and historical and cultural value.

As mentioned in pervious part, the principle and indicators of livability and new development are mentioned, it is visible that these indicators has some relation in different part which lead us that it has direct relation between livability and new development in historic area. These relations are showed in table below.

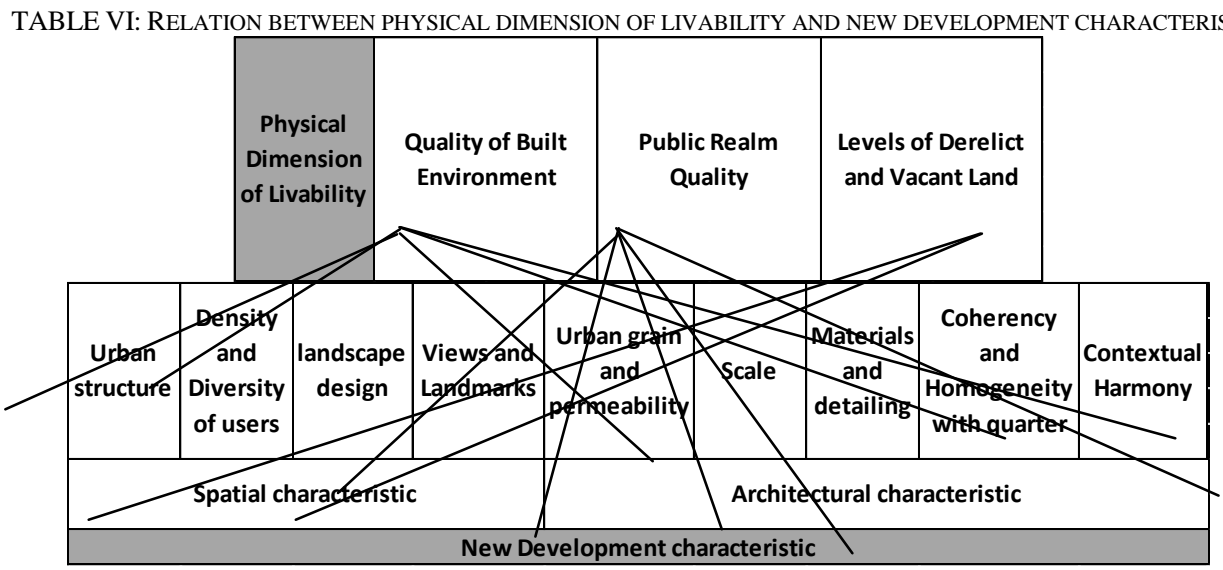

As mentioned in pervious part, it is obvious that the parameters and indicators of livability which shown in pervious table has relation with new development characteristic, for example one of the indicator of quality of built environment is "density" and in spatial characteristic of new development also density and mix is visible too. The rest of the relation between dimension of livability and new development characteristic will be shown in further tables.

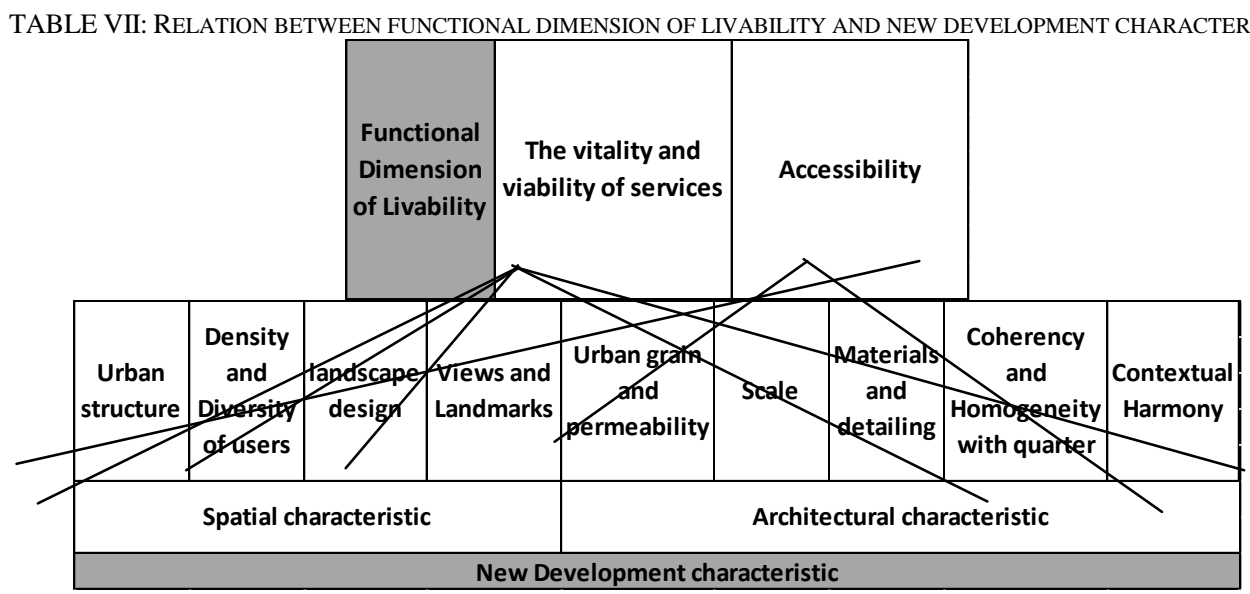


For social and safety dimension, it depends on the condition of the historic urban quarter and the different kind of social interaction between the people. Also the safety dimension it depends on different policy and principle which the society determines for the people and it could be variable for different place due to different culture. As shown in pervious part, it could be revealed that the livability and new development characteristic has direct relation between each other. So it could be possible to reach the livability in area by new development, and new development act as a tool to support and lead to livability. But the new development should be in correct direction and respect to cultural and historic heritage of the area and it has to be effective for area.

Cyprus is located in the north east part of Mediterranean Sea. As being ruled by different conquerors, the island owned many different cultures, the Byzantine, Lusignan, Venetian, Genoese, Ottomans, Turks and Greeks. Intermitting culture reflected in a distinctive historical and cultural heritage, which makes up the unique identity of cities. After 1974 due to political reason, Cyprus is divided into two parts, the north part and the south part, Famagusta which is the case study of this research is located in the north part of the island. The case study for this article is the Walled city of Famagusta, North Cyprus. As mentioned in pervious part, this article is used the data and analysis of master thesis which related to livability of Walled city of Famagusta. As it revealed in that research, it showed that the livability of the Walled city of Famagusta is in low level, the total result of measurement is 70 and the average result should be 93, so the measurement for Walled city of Famagusta is below average. From this measurement it is understandable that the Walled City of Famagusta is not livable and the result of measurement is below average so it needs the new guidelines, proposal plans and new policies to reach the livability (Mousavi, 2013). The methodology for the information and data in this study is evaluated by the "Likert Scale". As McCall stated one of the way to understand the needs and evaluate the problem is using the "Likert Scale". The evaluation in "Likert Scale" is numerical and it could be evaluated for each element separately (Mousavi, 2013).

TABLE IX: LIVABILITY EVALUATION

\begin{tabular}{|c|c|c|}
\hline Livability Evaluation & Below Average & Above Average \\
\hline Total Result & $\mathbf{0 - 9 2}$ & $\mathbf{9 3 - 1 5 4}$ \\
\hline Vital Needs & $\begin{array}{c}\text { New guidelines, } \\
\text { proposal plan and } \\
\text { new policies }\end{array}$ & $\begin{array}{c}\text { Improvement, } \\
\text { rehabilitation, } \\
\text { conservation and } \\
\text { revitalization plan }\end{array}$ \\
\hline
\end{tabular}

\section{CONCLUSION}

Introductory research on livability concept revealed that it has relation with quality of life and quality of place. The dimension of livability by focusing on physical, functional, social and safety dimension is stated. Accordingly the livability in historic urban quarters and the relation between new development parameters and livability dimension and indicators is mentioned in detail. At last the Walled city of
Famagusta as a case study and revealed that it is not livable, so some suggestion and recommendation will be mentioned which related to new development and it could change the livability level in Walled city of Famagusta.

- Encourage and promotes construction companies and builders to use the proper material for the building to reach the proper texture in area and harmony in façade.

- Propose a well-designed public space for area to provide a place for people to come and spend their free time.

- Proposing a variety of function and utilizations to keep the public place livable and active.

- Providing a place for people and citizen who they could be relaxed there, and proposing some places for social interaction.

- Increase the variety of function in the whole area to invite diversity of users to come to place and keep the place livable and active.

- Propose proper and appropriate function and activities in vacant land and building to reach the proper livability level by diversity of function in vacant and derelict land.

- Improving the effectiveness of services in commercial zone and provide new facilities and functions in these areas to keep the citizens and user satisfy in area.

- Try to avoid keeping the vacancy building and land in commercial area to increase the livability.

- Propose well-designed and compatible street furniture and landscape elements to increase the street scape level and also livability level.

- Propose the cycling ways in area to attract variety of people to come to area and increase the livability.

- Propose the proper public transportation facilities to provide public services for citizens and people.

- By proposing the proper function for historic buildings to reach the diversity of function and users.

\section{REFERENCES}

[1] Balsas, C. (2010). Measuring the livability of an urban center: an exploratory study of key performance indicators. Planning Practice \& Research, 19(1).

[2] Doratli, N. Onal Hoskara, S. Fasli, M. (2004). An analytical methodology for revitalization strategies in historic urban quarters: a case study of the Walled City of Nicosia, North Cyprus

[3] Kaal, H. (2011). A conceptual history of livability. City 15(5). https://doi.org/10.1080/13604813.2011.595094

[4] Leby, J. (2010). Livability Dimensions and Attributes: Their Relative Importance in the Eyes of Neighborhood Residents. Journal of Construction in Developing Countries, 15(1).

[5] Mousavi, S.N. (2013). Livability in Historic Urban Quarters, Case Study: Walled City of Famagusta, Master Thesis, Eastern Mediterranean University.

[6] Tiesdell, S. OC, T \& Heath, T. (1996). Revitalizing Historic Urban Quarters. Architectural Press.

[7] Yeang, L. (2006). Quality of Place: The North's Residential Offer Phase I. Llewelyn Davies Yeang.

[8] Yeang, L. (2006). Quality of Place: The North's Residential Offer Phase 1la. Llewelyn Davies Yeang. 